\title{
Analyzed Psychological Impact Of An Effect Of Covid-19 On Mental Health On Health Personnel In Hospital Putri Hijau Medan
}

\author{
Dessy Series Ulina Ginting ${ }^{1}$, Santy Siregar ${ }^{2 *}$, Yolanda Eliza Putri Lubis ${ }^{3}$, Chrismis Novalinda Ginting ${ }^{4}$ \\ 1,2,3,4 Program Study Master Of Biomedic Science Faculty Of Medicine \\ Universitas Prima Indonesia Medan, North Sumatera, Indonesia \\ * Corresponding author: \\ Email: santysiregar@unprimdn.ac.id
}

\begin{abstract}
.
The performance of nurses in hospitals is closely related to reliable, skilled, and professional human resources. Many factors that make it difficult for a person to care for a child are, in fact, length of work, training, motivation, incentives, work environment, and supervision.This research is for the treatment of the factors that is used in the preparation of nurse performance an analytical study with a cross-sectional approach (cross sectional). The research was conducted at Raden Mattaher Hospital, Jambi Province was 406 people and a sample of 261 people. Sampling by purposive sampling. Analyze the data with univariate, bivariate with chi-square test, and multivariate with multiple logistic regression at $95 \%$ confidence level (\lrcorner$=0.05)$. The results showed that The factors in the development of Rumar General Hospital Raden Mattaher Jambi Province are education and training $(p=0.000)$, motivation $(p=0.000)$, incentives $(p=0.020)$, and supervision $(p=0.002)$. The variable that has no effect is age $(p=0.584)$, education $(p=0.786)$, length of work $(p=0.421)$, and work environment $(p=0.166)$. The most dominant variable affecting the performance of nurses is motivation with a value of $\operatorname{Exp}(B) / O R=5.626$, meaning that nurses who have high motivation have a 5.6 times higher chance of good performance than nurses with low motivation.
\end{abstract}

Keywords: Nurse Performance, Training, Motivation, Incentives, Supervision.

\section{INTRODUCTION}

Pandemic Corona Virus Disease-19 (Covid-19) is a device that can be used to control cells that have a multisector (bio-psycho-social-spiritual) dimension that converts and fears because there is a lot of misremembered information. Pandemic Covid-19 is not known as a physical physician, but also as a mental health practitioner who has been practiced for a long time by Covid-19(Harmony of Hope Cabinet, 2020).World Health Organization (WHO) reports that up to May 2021 at least 115,000 health workers are estimated to have died due to exposure to Covid-19 (Euronews, 2021). Meanwhile, in October 2020, as many as 1,500 nurses in 44 countries died from Covid-19, the same number as the number of nurses who died in the First World War. The exact number of deaths of health workers is unknown in all countries in the world because there is no standard data collection mechanism for infection and nurse deaths.(Castella, 2021).The number of Covid-19 patients continues to increase but is not matched by the readiness of facilities and an adequate number of medical personnel, resulting in health workers experiencing an increase in their workload and fatigue both physically and mentally.(Artiningsih \& Chisan, 2020).Health workers have difficulty maintaining mental health conditions such as anxiety, stress, and depression. Factor risk factors such as the identification of the virus in the kidneys, the disease of the disease, the disease, the disease and the disease of the Covid-19 disease and social stigma(Rosyanti \& Hadi, 2020).

Several previous studies have proven that the health of health workers is related to the psychological impact during the Covid-19 pandemic. Literature study conducted by Uphoff et al., (2021)from research in various countries, that from an inventory of risk and protective factors mostly for health workers, shows the importance of practical and emotional support in the workplace, which in turn can affect personal characteristics that are important for health. StudyUntilo, et al. (2021)in Portugal, that factors directly related to the Covid-19 outbreak experienced by health workers were symptoms of depression, anxiety and stress. StudyCheng (2020) in China concluded that some health workers experience mental health disorders such as anxiety because the supply of personal protective equipment has not been met when taking action to patients. Study Nasrallah (2020) who researched in 8 Indonesian archipelago Indonesia has health workers in 
Indonesia experiencing anxiety due to the Covid-19 outbreak, experiencing stress, and experiencing depression. It is a correlation that can be taken to reduce stress, anxiety, depression, mental illness and anxiety when it comes to the Covid-19 pandemic.Further research Titasari \& Fani (2021) also get the result that most of the officers experienced depression, anxiety, and also experienced stress. The Covid-19 Pandemic Wave team will host a selection of world in situations related to the size and size of the bikah extreme pressure(Greenberg, et al., 2020). Therefore, health workers are an important component to address large-scale public health problems. Interventions for the prevention and treatment of mental health of health workers are very important(El-Hage, 2020).

Symptoms of post-traumatic stress disorder, nonspecific symptoms of anxiety and depression are the main manifestations of mental health disorders experienced by health workers(Stuijfzand et al., 2020). Stress, kExcessive anxiety and depression can have a detrimental effect on the mind and body of health workers and can even cause physical illness, lowering the body's resistance so that there is a risk of contracting Covid-19(Dinah \& Rahman, 2020).Putri Hijau Hospital Level II Medan is one of the Class B General Hospitals in the city of Medan with the code RS 1275035 under the ownership of the TNI-AD and accredited Plenary from KARS SNARS version ED 1. Based on data from Putri Hij Hospital the number of patients with Covid-19 19 confirmed cases at the Putri Hijau Hospital Level II in Medan from early 2020 to August 2021 as many as 873 cases. The highest number of cases in May 2021 was 167 cases. The number of patients who recovered as many as 742 people, and who died as many as 131 people. Putri Hijau Hospital Level II Medan is also prepared to be a hospital for handling Covid-19 isolation patients(Green Princess Hospital, 2021).Based on the description above, the researchers are interested in taking the title "Psychological Impact of the Effect of Covid-19 on Mental Health on Health Workers at Hospital Putri Hijau Level II Medan".

\section{LITERATURE REVIEW}

\subsection{Mental Health}

Mental comes from the Latin word mens, mentis which means soul, life, soul, spirit, and spirit, while hygiene comes from the Greek word. Hygiene is a very important product. So mental health science is a science that discusses the mental life of humans by viewing humans as a complex psychophysical totality(Semiun, 2016).Mental health is the realization of true harmony between mental functions and the creation of self-adjustment between humans and themselves and their environment, based on faith and devotion, and aims to achieve life.

This definition includes a very important element of religion and efforts must be made to apply it in life, in line with the application of mental health principles and the development of good relations with fellow human beings.(Daradjat, 2016).Hawari (2017)also said that the notion of mental health according to the understanding of medical science is a condition that allows optimal physical, intellectual and emotional development of a person and that development runs in harmony with the circumstances of others. Therefore, the meaning of mental health has characteristics that are harmonious (harmonious) and pay attention to all aspects of human life and in relation to other humans.

\subsection{Concept Stress}

Stress is a Responseadoptive to a situation that is felt to be challenging or threatening a person's health. People feel stressed because of too much work, lack of understanding of work, too heavy a load of information or because of the times(Sopiah, 2016). According to Luthans inSedarmayanti (2015) Stress as a response in adapting which is influenced by individual differences and psychological processes, as a consequence of environmental actions, situations or events that hold too many psychological and physical demands on a person. Stress Is a condition of dependence that creates a physical and psychological imbalance that affects the emotions of the thinking process and the condition of an employee, too much stress can threaten a person's ability to deal with the environment. (Rivai, 2014).Gibson (2014)Expressing job stress is conceptualized from several points of view, namely stress as a stimulus, stress as a response and stress as a stimulus-response. Stress as a stimulus is an approach that focuses on the environment. The 
definition of stimulus views stress as a force that pressures individuals to respond to stressors. This approach views stress as a consequence of the interaction between environmental stimuli and individual responses.

The stimulus-response approach defines stress as a consequence of the interaction between environmental stimuli and individual responses. Stress is seen as not just a stimulus or response, but stress is the result of a unique interaction between environmental stimulus conditions and the individual's tendency to respond.Ivancevich \& Matteson (2013)states that work stress occurs in employees not only because of conflict but other factors that influence, including: (1) role ambiguity and role conflict, (2) work overload, (3) responsibility for career development, (5) lack of group cohesion, (6) inadequate group support, (7) task practicality, and (8) leadership volume.Discussing stress, it can't be separated from stresssorry. Stressor is a cause or source of stress. Stress itself can be physical, for example a tiring task because it cannot be abandoned, and stressors can also be psychological such as mental pressure caused by unfair treatment, for example the attitude of superiors against the bottom.(Frasser, 2014).Basically, various sources of work stress are classified into two parts including: In work, there is workload, unbalanced authority, job ambiguity, unpleasant work environment, unpleasant co-workers, while from outside work financial worries, family life is not harmonious and negative behavior of family members(Siagian, 2014).

\subsection{Anxiety Concept}

Anxiety comes from the Latin, namely anxiousand then anxiety in English which means anxiety, is a word used by Freud to describe a negative effect and arousal(Jatman, 2013).Anxiety is a mood disorder (affective) which is characterized by feelings of deep fear or worry and does not experience disturbances in assessing reality, personality is still intact, behavior can be disturbed but still within limits.(Hawari, 2015).according to Stuart \& Sundeen (2014), anxiety / anxiety is closely related to feelings of uncertainty and helplessness. Emotional states have no specific object. Conditions are experienced subjectively and communicated in interpersonal relationships. Anxiety is different from fear, which is an intellectual judgment of something dangerous. Anxiety is an emotional response to that assessment.According to Hawari (2015)The complaints that are often raised by people with anxiety disorders include:

1. Anxious, worried, bad feeling, afraid of his own mind, irritable.

2. Feeling tense, restless, restless, easily startled.

3. Fear of being alone, afraid of crowds and people.

4. Disturbed sleep patterns, stressful dreams.

5. Concentration and memory disorders.

6. Somatic complaints such as pain in muscles and bones, ringing in hearing, palpitations, shortness of breath, indigestion, urinary disorders, headaches, and so on.

In addition to these general anxiety complaints, there is another group of anxiety that is more severe, namely anxiety disordersgeneralized anxiety disorder, panic disorder, phobic disorder and obsessivecompulsive disorder. according to Stuart \& Sundeen (2014), capacities to increase the number of required for survival, but the level of severe anxiety is not compatible with life. The most important thing is to know how to make a light, medium and heavy.

\section{METHODS}

The type of research that is used by the research is in the research study of analyticsquantitative, namely research conducted to obtain explanations to be studied. Quantitative analytical research aims to analyzethe psychological impact of complaining of Covid-19 on mental health for health workers at the Putri Hijau Hospital Level II Medan. The research design used was cross sectional, namely the research variables were examined directly at the time of the study.Population is a generalization area consisting of objects or subjects that have certain quantities and characteristics determined by the researcher to be studied and then conclusions are drawn. (Sugiyono, 2015). The target population in this study were all 215 health workers at Hospital the Putri Hijau Level II Medan.Sample is a collection of items from the Overall object that are displayed and displayed by the population (Notoatmodjo, 2018). The sample in this study is part of the population whose size is taken using the Slovin formula as follows: 


$$
n=\frac{N}{1+N\left(d^{2}\right)}
$$

Where:

n: sample size

$\mathrm{N}$ : population size

$\mathrm{d}$ : The mean of the mean and the mean difference $(\alpha=0.10)$

Then the number of samples in this study are:

$$
\begin{aligned}
& n=\frac{215}{1+215\left(0,1^{2}\right)} \\
& n=\frac{215}{1+215(0,01)} \\
& n=\frac{215}{1+2,15} \\
& n=\frac{215}{3,15}
\end{aligned}
$$

$=68.3$ or double 68 people

Based on these calculations, a sample of 68 people from 215 health workers at Putri Hijau Hospital Level II Medan was obtained. Sampling was done by purposive sampling (purposive sampling), namely selecting samples based on the researcher's considerations.

Validity test is used to measure whether an instrument is valid or not, meaning that it is able to reveal what is being measured. The validity test was conducted at RSU Royal Prima Medan as many as 30 people. The test carried out is to determine the correlation between the questions and the total score of the construct or variable. A construct is declared valid if there is a positive and significant correlation. The best correlations of 0.361 or the Corrected Indicator-Total Correlation on the output SPSS increase of 0.361 are measured by Pearson Product Moment(Ghozali, 2015). In this study, the validity of the questionnaire that was tested was only the mental health variable of health workers, while the other variables used a standardized questionnaire.

Table 1. Results of the Validity Test of the Health Worker Support Variable Questionnaire

\begin{tabular}{cllll}
\hline No. & Variable & r-count & r-table & Note. \\
\hline 1. & Mental health of health workers-1 & 0.620 & 0.361 & Valid \\
2. & Mental health of health workers-2 & 0.712, & 0.361 & Valid \\
3. & Mental health of health workers-3 & 0.902 & 0.361 & Valid \\
4. & Mental health of health workers-4 & 0.597 & 0.361 & Valid \\
5. & Mental health of health workers-5 & 0.909 & 0.361 & Valid \\
6. & Mental health of health workers-6 & 0.610 & 0.361 & Valid \\
7. & Mental health of health workers-7 & 0.479 & 0.361 & Valid \\
8. & Mental health of health workers-8 & 0.631 & 0.361 & Valid \\
9. & Mental health of health workers-9 & 0.609 & 0.361 & Valid \\
10. & Mental health of health workers-10 & 0.847 & 0.361 & Valid \\
11. & Mental health of health workers-11 & 0.529 & 0.361 & Valid \\
12. & Mental health of health workers-12 & 0.845 & 0.361 & Valid \\
13. & Mental health of health workers-13 & 0.599 & 0.361 & Valid \\
14. & Mental health of health workers-14 & 0.519 & 0.361 & Valid \\
15. & Mental health of health workers-15 & 0.803 & 0.361 & Valid \\
16. & Mental health of health workers-16 & 0.433 & 0.361 & Valid \\
17. & Mental health of health workers-17 & 0.668 & 0.361 & Valid \\
18. & Mental health of health workers-18 & 0.499 & 0.361 & Valid \\
19. & Mental health of health workers-19 & 0.802 & 0.361 & Valid \\
20. & Mental health of health workers-20 & 0.504 & 0.361 & Valid \\
\hline
\end{tabular}




\section{ANALYZE AND RESULT}

\subsection{Description of Research Site}

Tk II Putri Hijau Hospital in Medan, which is more than half a century old, is a hospital of pride for TNI residents. Apart from being a health service center for members of the TNI, TNI PNS and their families at the Tk II Putri Hijau Hospital in Medan also provide health services for the general public. In its journey since its establishment in 1950, with conditions that are all too lacking, the Tk II Putri Hijau Hospital in Medan has played a very important role in providing health support both in operating tasks, education and training, as well as improving health degrees.During the years 1954 - 1960 to assist the four existing wards, several facilities were built including the Administration Office, TPT head room, X-ray room, laboratory, pharmacy (medicine room), laundry room and kitchen, officer's treatment room and office. Subsequently, it underwent a lot of development of supporting facilities, namely:

1. In 1962, room VII, room VIII, room IX were built by the Kodam engineers.

2. In 1963 the "Sasana Karya Tama" hall was built by the Command. Several doctors celebrated the wedding in this hall.

3. In 1965, room X was built by PT. Kesawan.

4. In 1966 the administration building was handed over by Ka. Kesrem / Garnizun Medan.

5. In 1967, the Nursing Management School (SPR) I was opened with 30 students.

6. This education in 1981 changed to the School of Health Nurses (SPK)

7. In 1968 the handover of the physiotherapy building and pharmacy from the funds from the Fancy Fair Charity Kesdam II / BB which was inaugurated on June 21, 1968 by the Head of Kesdam II / BB Brigadier General Dr. Ibrahim Iran.

8. In 1970 the Putri Hijau Tk II Hospital was named the largest hospital in all of Indonesia

Until now the Tk II Putri Hijau Medan Hospital has been led by 28 Hospital Heads, three years running the Tk II Putri Hijau Medan Hospital has sent personnel to support DI / TII operations (1953), the following year 1954), health support in PRRI operation (1957), Student Sports Week Health Team (1960), as UN Peace Ambassador by participating in the Garuda III Contingent to Congo (1963), PGRS Operation / Paraku West Kalimantan (1973), East Timor Operation (1976-1998) and Operation Military by Aceh Special Region will be held by Aceh Earthquake \& Tsunami - Nias.Hospital Tk II Putri Hijau Medan has facilities such as medical check-up units, general support facilities, medical support facilities, inpatient facilities, outpatient facilities, and emergency facilities. The Medical Check Up Unit at Putri Hijau Hospital is one of the units that serves health checks for members of the TNI, civil servants \& the general public with the aim of knowing health conditions both in healthy and sick conditions, to improve the quality of health services on a regular basis.MCU Service Clinicwith service hours: Monday - Friday at $08.00-12.00 \mathrm{Wib}$ To carry out a Medical Check Up examination from an Institution / Business Entity / Institution, you are requested to bring a letter of request for an examination from the Institution. Medical Check Up Place by MCU Building 1st (One)Floor.General Supporting Facilities at the Tk II Putri Hijau Hospital in Medan, namely Administration, Educational Installation, Nutrition Installation, Laundry, Body Room, 2 Room Hall, Warehousing, Canteen, Garage, Wastewater Treatment Plant.

The facilities offered by Tk II Putri Hijau Hospital Medan include: Medical Rehabilitation / Physiotherapy, Surgery Room, Clinical Laboratory Unit, Radiology Unit, USG and CT Scan, Pharmacy.Hospital Inpatient Facility Tk II Putri Hijau Medan or also known as Hospitalization is a term where patients in a hospital must undergo a treatment process that is handled by doctors according to their illness. Patients who are hospitalized in a certain room and will usually have an IV in their hand. VVIP room, providing comfort and tranquility as well as excellent service with facilities of 2 beds, 1 electric bed for the patient and 1 bed for the waitstaff, 1 wardrobe, 1 refrigerator, 2 TVs, 1 Sofa Set, 1 Dining Table Set, 2 bathroom, 2 AC units. VIP room, providing comfort and tranquility as well as excellent service with 1 electric bed, wardrobe, refrigerator, TV, sofa, bathroom, air conditioning. Class I (One) room, providing comfort and tranquility and excellent service with 1 bed facilities, wardrobe, TV, Bathroom, Table and Chairs. Class II (Two) room, equipped with bed, AC, wardrobe, table, chair, TV, bathroom. Class III (Three) room, equipped with bed facilities, air conditioning, wardrobe, desk, TV, bathroom. ICU Treatment Room, 
equipped with bed facilities, AC, Central Oxygen, Ventilator, Bed Monitor, bathroom.Based on the research results, the characteristics of the respondents include gender, education, and length of work. More details can be seen on the following tablet.

Table 2. Distribution of Frequency Responses Based on Characteristics at Putri Hijau Hospital Level II Medan in 2021

\begin{tabular}{llll}
\hline No & Gender & f & \% \\
\hline 1. & Woman & 7 & 10.3 \\
2. & Man & 61 & 89.7 \\
\hline Amount & $\mathbf{6 8}$ & $\mathbf{1 0 0 . 0}$ \\
\hline No & Last education & f & \% \\
\hline 1. & D3 & 58 & 85.3 \\
2. & S1 & 10 & 14.7 \\
\hline Amount & $\mathbf{6 8}$ & $\mathbf{1 0 0 . 0}$ \\
\hline No & Length of working & $\mathbf{f}$ & $\mathbf{\%}$ \\
\hline 1. & 1-10 years & 35 & 51.5 \\
2. & 11-20 years & 25 & 36.7 \\
3. & 21-30 years & 8 & 11.8 \\
\hline Amount & $\mathbf{6 8}$ & $\mathbf{1 0 0 . 0}$ \\
\hline
\end{tabular}

Table 2. above, it is known that most of the respondents are female as many as 61 people (89.7\%), a small proportion are male as many as 7 people $(10.3 \%)$. Based on the latest education, most of the respondents had D3 education as many as 58 people $(85.3 \%)$, a small portion had S1 education as many as 10 people (14.7\%). Based on the length of work, most of the respondents worked in the hospital for 1-10 years as many as 35 people $(51.5 \%)$, a small proportion of respondents had worked for 21-30 years as many as 8 people $(11.8 \%)$.

\subsection{Analysis}

Based on the results of the study, the variables of age, stress, anxiety, depression and mental health of health workers at Putri Hijau Hospital Level II Medan can be seen in the following tablet.

Table 3. Frequency Distribution Respondents Based on Age, Stress, Anxiety, Depression and Mental Health Variables of Health Workers at

Putri Hijau Hospital Level II Medan in 2021

\begin{tabular}{llll}
\hline No. & Age & f & \% \\
\hline 1. & $20-40$ years & 56 & 82.4 \\
2. & $41-60$ years & 12 & 17.6 \\
\hline Amount & & $\mathbf{6 8}$ & $\mathbf{1 0 0 . 0}$ \\
\hline No. & Stress & $\mathbf{f}$ & $\mathbf{\%}$ \\
\hline 1. & Light & 30 & 44.1 \\
2. & Heavy & 38 & 55.9 \\
\hline Amount & & $\mathbf{6 8}$ & $\mathbf{1 0 0 . 0}$ \\
\hline No. & Worried & $\mathbf{f}$ & $\mathbf{\%}$ \\
\hline 1. & Light & 31 & 45.6 \\
2. & Heavy & 37 & 54.4 \\
\hline Amount & & $\mathbf{2 6 1}$ & $\mathbf{1 0 0 . 0}$ \\
\hline No. & depression & $\mathbf{f}$ & $\mathbf{\%}$ \\
\hline 1. & Light & 54 & 79.4 \\
2. & Heavy & 14 & 20.6 \\
\hline Amount & & $\mathbf{6 8}$ & $\mathbf{1 0 0 . 0}$ \\
\hline No. & Mental Health Health Workers & $\mathbf{f}$ & $\mathbf{\%}$ \\
\hline 1. & Once & 173 & 66.3 \\
2. & Never & 88 & 33.7 \\
\hline Amount & & $\mathbf{2 6 1}$ & $\mathbf{1 0 0 . 0}$ \\
\hline
\end{tabular}

Tables 3 above shows that most of the health workers at the Putri Hijau Hospital Level II Medan studied were aged between 20 years - 40 years as many as 56 people (82.4\%), a small proportion aged 41-60 as many as 12 people (17.6\%).Based on The depreciation rate is the average of the rate at which the respondent responds to the depreciation rate of 54 percent $(79.4 \%)$, the rate of the depreciation rate at the rate of 14 percent $(20.6 \%)$. Based on mental health, most of the respondents' mental health in the adaptive 
category were 42 people $(61.8 \%)$, a small portion of the respondents' mental health in the maladaptive category were 26 people (38.2\%).

\subsection{Multivariate Analysis.}

This multivariate analysis aims to analyze the factors that affect the mental health of health workers during the Covid-19 pandemic. Simultaneously, multivariate data analysis was carried out using multiple logistic regression tests through several steps.

1) Conducting the selection of variables that have the potential to be included as candidate models. The variables selected as candidates are variables that have a significant value.

2) In this model, variables that are candidates for variables that have a value of $<<25$ in bivariate analysis (or chi-square) that are similar in size to the multivariate analysis. The use of statistical significance of 0.25 as a requirement in multiple logistic regression tests to allow variables that are hiddenly considered to be less related are actually very important to be included in the multivariate model.

3) Based on the results of bivariate analysis, the variables that can be used as candidate models in the multiple logistic regression test in this study because they have a significant value $<0.25$ as many as 4 variables, namely age $(p=0.007)$, stress $(p=0.000)$, anxiety $(p=0,00)$, and depression $(p=0.000)$.

4) Furthermore, testing with multiple logistic regression simultaneously with the forward conditional method was carried out to identify the most influential variables on the mental health of health workers. The forward conditional method is to enter the variables one by one from the results of the correlation of variables and meet the statistical significance criteria to enter the model, until all the variables that meet these criteria are included in the model. Variables that are related to each other are variables that have a partial correlation coefficient with variable dependencies and that meet criteria that are relevant to their model.

Based on hThe results of the multiple logistic regression test that has been carried out show that all variables affect the mental health of health workers, namely age, stress, anxiety and depression. The complete multiple logistic regression test results can be seen in the following tablet.

Table 4. Multiple Logistics Regression Test Results

\begin{tabular}{lllll}
\hline Variable & B & sights. & Exp (B) & $\begin{array}{l}\text { 95\% CI for Exp } \\
\text { (B) }\end{array}$ \\
\hline Age & 2,372 & 0.015 & 10,716 & $1,573-52,983$ \\
Stress & 1,720 & 0.026 & 5.586 & $1.223-25.523$ \\
Worried & 1,597 & 0.039 & 4,938 & $1.085-22,479$ \\
depression & 2,776 & 0.009 & 16,053 & $2,009-68,264$ \\
Constant & -5.849 & 0.000 & & \\
\hline
\end{tabular}

All of the variables studied had an effect on the mental health of health workers during the Covid-19 pandemic at the Putri Hijau Hospital Level II Medan with a p value of 0.000. Meanwhile, for each variable the significant values were as follows: age $(p=0.015)$, stress $(p=0.026)$, anxiety $(p=0.039)$, and depression $(p=0.009)$. The dominant variable or the greatest influence on the mental health of health workers during the Covid-19 pandemic in this study was the depression variable which had a value of Exp (B) / OR $=16,053$ meaning that health workers who had malecephalus depression were 16 times higher than health workers who have mild depression.

The age variable which has a value of $\operatorname{Exp}(\mathrm{B}) / \mathrm{OR}=10.716$ means that health workers aged 41-60 years have a mental health opportunity in the maladaptive category of 10.7 times higher than health workers aged 21-40 years. Variable stress in the $\exp \operatorname{Exp}(\mathrm{B}) / \mathrm{OR}=5.586$ means that health workers who experience severe stress, have a 5.5 times higher chance of mental health in the maladaptive category than health workers who experience mild stress.Anxiety variable that has an $\operatorname{Exp}(\mathrm{B}) / \mathrm{OR}=4.938$ value means that health workers who experience severe anxiety have a 4.9 times higher chance of mental health in the maladaptive category than health workers who experience mild anxiety.

\section{CONCLUSION.}

Based on the results of the research that has been carried out and have been presented in the previous chapter can be concluded as follows: 
1. The researcher got the characteristics of respondents based on gender at the Putri Hijau Hospital Level II Medan the majority of respondents were female (89.7\%) and respondents were male $(10.3 \%)$, the majority of respondents had D3 education (85.3\%) and minorities are dependent on S1 (14.7\%). The majority of respondents to work in the hospital for $1-10$ years $(51.5 \%)$, and the minority 21-30 years (11.8\%).

2. Age affects the mental health of health workers at Putri Hijau Hospital Level II Medan in 2021, p = $0.015<0.05$.

3. Stress affects the mental health of health workers at the Putri Hijau Hospital Level II Medan in 2021, $\mathrm{p}=0.026<0.05$.

4. Anxiety affects the mental health of health workers at the Putri Hijau Hospital Level II Medan in $2021, \mathrm{p}=0.039<0.05$

5. Depression affects the mental health of health workers at the Putri Hijau Hospital Level II Medan in $2021, \mathrm{p}=0.009<0.05$.

\section{REFERENCES}

[1] Alwisol. (2015). Personality Psychology (Print 2). Jakarta: Kanisius.

[2] Amir, N. (2016). Depressed Neurobiological Aspects of Diagnosis and Management. Jakarta: Publishing Agency of the Faculty of Medicine, University of Indonesia.

[3] Artiningsih, RA, \& Chisan, FK (2020). Burnout and Commitment to Duty: Challenges of Medical Workers in Facing the Covid-19 Pandemic Proceedings of the LP3M National Seminar, 1 (1), 1-9.

[4] Azwar, S. (2016). Human Attitude, Theory and Its Measurement (Print 5). Yogyakarta: Student Library.

[5] BBC. (2021). The death toll from health workers in Indonesia due to Covid-19 is the highest in Asia. Retrieved September 29, 2021, from bbc.com website: https://www.bbc.com/indonesia/indonesia-58345226

[6] Cai, H., Tu, B., \& Ma, J. (2020). Psychological Impact and Coping Strategies of Frontline Medical Staff in Hunan Between January and March 2020 During the Doutbreak of Coronavirus Disease 2019 (Covid-19) in Hubei, China. Med Sci Monit, 26(1), e924171.

[7] Cai, W., Lian, B., Song, X., Hou, T., Deng, G., \& Li, H. (2020). A Cross-Sectional Study on Mental Health Among Health Care Workers During The Outbreak of Corona Virus Disease 2019. Asian J Psychiatry, 51 (2), 102111.

[8] Castella, T. De. (2021). WHO says 'at least' 115,000 health workers have now died from Covid-19. Retrieved September 30, 2021, from nursingtime website: https://www.nursingtimes.net/news/coronavirus/who-says-atleast-115000-health-workers-have-now-died-from-covid-19- 27-05-2021/

[9] Chaplin, JP (2017). Complete Dictionary of Psychology (Print 5; Kartini Kartono, Ed.). Jakarta: Raja Grafindo Persada.

[10] Cheng, Q. (2020). Correspondence Mental health care for medical staff in China during the COVID-19. Lancet, $7(1), 15-26$.

[11] Coleman, JC (2016). Contemporary Psychology and Effective Behavior (4th Ed.). Glenview: Scott Forestman and $\mathrm{CO}$.

[12] Daradjat, Z. (2016). Mental Health (Print 6). Jakarta: Haji Masagung.

[13] Dinah, \& Rahman, S. (2020). Overview of Nurse Anxiety Levels During the Covid 19 Pandemic in Developing and Developed Countries: A Literature Review. Health Dynamics Journal of Midwifery and Nursing, 11(1), $37-48$.

[14] El-Hage, W. (2020). Health professionals facing the coronavirus disease 2019 (COVID-19) pandemic: What are the mental health risks? L'Encéphale, 46 (3), S73 - S80. Retrieved from https://doi.org/10.1016/j.encep.2020.04.008

[15] Euronews. (2021). COVID-19: An estimated 115,000 healthcare workers have died from disease, says WHO. Retrieved September 29, 2021, from euronews.com website: https://www.euronews.com/2021/05/24/covid-19estimated-115-000-health-workers-have-died-from-disease- says-who

[16] Frasser, TM (2014). Stress and Job Satisfaction (Print 2). Jakarta: Binawan Pressindo Library.

[17] Friedman, M. (2017). Textbook of Family Nursing: Research, Theory, and Practice. Jakarta: EGC Medical Book Publisher.

[18] Ghozali, I. (2015). Application of Multivariate Analysis with the SPS Program (Print 7). Semarang: University of Diponegoro Press. 
[19] Gibson, JL (2014). Organization and Management: Behavior, Structure, and Process (Print 9; J. Wahid, Ed.). Jakarta: Erlangga.

[20] Greenberg, N., Docherty, M., Gnanapragasam, S., \& Wessely, S. (2020). Managing mental health challenges faced by healthcare workers during the Covid-19 pandemic. BMJ, 368 (m1211), 1-4.

[21] Hawari, D. (2015). Management of Stress, Anxiety, and Depression (Print 5). Jakarta: Faculty of Medicine University of Indonesia.

[22] Hawari, D. (2017). Management of Stress, Anxiety and Depression. Jakarta: FKUI Publishing Center.

[23] Hendy, A., Abozeid, A., Sallam, G., Fattah, HAA, \& Reshia, FAA (2021). Predictive factors affecting stress among nurses providing care at COVID-19 isolation hospitals at Egypt. Nursing Open, 8(1), 498-505. https://doi.org/10.1002/nop2.652

[24] Hurlock, EB (2017). Developmental Psychology: A Across the Range Approach. Life (Print 6). Jakarta: Erlangga.

[25] Ivancevich, JM, \& Matteson, MT (2013). Organizational Behavior and Management (Print 8). Jakarta: Index.

[26] Jatman, D. (2013). Psychology of the Soul (Print 3). Yogyakarta: Cultural Landscape Foundation.

[27] Asa Harmony Cabinet. (2020). Pandemic and Mental Health: Summarizing Mental Health Issues during a Year in the Pandemic Era. Yogyakarta: Department of Advocacy and Strategic Studies BEM KM FKG UGM 2020.

[28] Kaplan. (2016). Psychiatry Synopsis: The Behavioral Science of Clinical Psychiatry (Print 3). Jakarta: Literature Development.

[29] KBBI. (2018). Big Indonesian Dictionary (KBBI). Jakarta: Balai Pustaka.

[30] Indonesian Ministry of Health. (2018). Classification and Codefication of Diseases and Related Problems III (Print 1). Jakarta: Ministry of Health of the Republic of Indonesia.

[31] Indonesian Ministry of Health. (2020). Guidelines for the Prevention and Control of Coronavirus Disease (COVID-19). Jakarta: Ministry of Health of the Republic of Indonesia.

[32] Indonesian Ministry of Health. (2021). Standard Guidelines for Doctor Protection in the Covid-19 Era. Jakarta: Ministry of Health of the Republic of Indonesia.

[33] Kuncoro. (2018). Family Social Support (Print 3). Bandung: Refika Aditama.

[34] Lai, J. (2020). Factors Associated With Mental Health Outcomes Among Health Care Workers Exposed to Coronavirus Disease 2019. JAMA, 3 (3), 1-12.

[35] Liang, Y., Chen, M., Zheng, X., \& Liu, J. (2020). Screening for Chinese medical staff mental health by SDS and SAS during the outbreak of Covid-19. Journal of Psychosomatic Research, 133(1), 110102.

[36] Lubis, NL (2019). Depression and Psychologists Review (Print 2). Jakarta: Prenada Media Group.

[37] Maben, J., \& Bridges, J. (2020). Covid-19: Supporting Nurses' Psychological And Mental Health. Journal Of Clinical Nursing, 29 (15), 2742-2750.

[38] Maramis, WF (2017). Mental Medicine. Surabaya: Airlangga University Press.

[39] Nasrallah, D. (2020). Psychological Impact of Health Workers in Efforts to Deal with the Corona Virus (Covid19) Pandemic in Indonesia. Sinta Ristekbrin, 1 (1), 25-34.

[40] Notoatmodjo, S. (2017). Promote Health and Health Behavior (PE Printing). Jakarta: Rineka Cipta.

[41] Notoatmodjo, S. (2018). Health Research Methodology (Print 5). Jakarta: Rineka Cipta.

[42] Perdoki. (2020). Guidelines for Protection for Workers in Health Service Facilities During the COVID-19 Pandemic. Jakarta: Indonesian Association of Occupational Medicine Specialists (PERDOKI).

[43] Plate, B., Opod, H., \& David, L. (2021). Psychological Impact of Health Workers During the Covid-19 Pandemic Journal of Biomedicine, 13 (2), 144-151.

[44] PPPK UGM. (2021). Mental Health and Psychosocial Support Related to the Covid-19 Outbreak. Yogyakarta: Faculty of Medicine, Public Health, and Nursing Universitas Gadjah Mada.

[45] Rivai, V. (2014). Human Resources Management for Companies (Print 2). Jakarta: RajaGrafindo Persada.

[46] Robbins, S. (2015). Organizational Behavior (Print 3). Jakarta: Prenhallindo.

[47] Rossi, R., Socci, V., Pacitti, F., DiLorenzo, G., DiMarco, A., \& Siracusano, A. (2020). Mental Health Outcomes Among Front and Second Line Health Workers Associated With the Covid-19 Pandemic in Italy. MedRxiv, 04 (16), 20067801.

[48] Rosyanti, L., \& Hadi, I. (2020). Psychological Impact in Providing Health Care and Services for COVID-19 Patients on Health Professionals. HIJP: Health Information Research Journal, 12(1), 107-130.

[49] Green Princess Hospital. (2021). Report on Handling Covid-19 at Putri Hijau Hospital Level II Medan in 2021. Medan: Putri Hijau Hospital Level II Medan.

[50] Sahara, W. (2021). Until the end of August 2021, 1,967 health workers in Indonesia died due to Covid-19. Retrieved September 28, 2021, from kompas.com2 website: 
https://nasional.kompas.com/read/2021/08/27/19573891/till-akhir-agustus-2021-1967-energi-kesehatan-diindonesia- die? page $=$ all

[51] Sampaio, F., Sequeira, C., \& Teixeira, L. (2021). Impact of COVID-19 outbreak on nurses' mental health: A prospective cohort study. Environ Res., 194(1), doi:10.1016 / j.envres.2020.110620.

[52] Sarwono, SW (2018). Theories of Social Psychology (Print 4). Jakarta: Rajawali Press.

[53] Sedarmayanti. (2015). Work Procedure and Work Productivity (An Overview of Ergonomics Aspects Or The Relationship Between Humans And The Work Environment (Print 3) Bandung: Mandar Maju.

[54] Semiun, Y. (2016). Mental Health 3 (Print 2). Yogyakarta: Kanisius.

[55] Siagian, SP (2014). Human Resource Management (Print 4). Jakarta: Earth Literacy.

[56] sopiah. (2016). Organizational Behavior (Print 3). Yogyakarta: Andi Press.

[57] Stuart, GW, \& Sundeen. (2016). Mental Health Nursing Principles and Practices. Jakarta: EGC Medical Book Publisher.

[58] Stuart, GW, \& Sundeen, JS (2014). Psychiatric Nursing Pocket Book (Print 6). Jakarta: EGC.

[59] Stuijfzand, S., Deforges, C., Sandoz, V., Sajin, CT, Jaques, C., \& Elmers, J. (2020). Psychological impact of an epidemic / pandemic on the mental health of healthcare professionals: a rapid review. BMC Public Health., 20(1), 12-30.

[60] Sugiyono. (2015). Educational Research Methods Quantitative, Qualitative and R\&D Approaches (Print V). Bandung: Alphabet.

[61] Suroso, AI (2016). The Effect of Stress in Work on Employee Performance: A Case Study in an Agribusiness Company PT. NICs. Journal of Agribusiness Management, 3(1), 19-30.

[62] Teguh, P. (2015). Mental Nursing Textbook (Print 1). Yogyakarta: Student Library.

[63] Titasari, NA, \& Fani, T. (2021). Psychological Impact of the Covid-19 Pandemic on Medical Record Officers. Proceedings of the Scientific Discussion, 1 (1), 74-81.

[64] Uphoff, EP, Lombardo, C., Johnston, G., Weeks, L., Rodgers, M., Dawson, S.,... Churchill, R. (2021). Mental health among healthcare workers and other vulnerable groups during the COVID-19 pandemic and other coronavirus outbreaks: A rapid systematic review. Plos One, 1 (1).

[65] Videbeck, SL (2018). Mental Nursing Textbook (Print 3). Jakarta: EGC Medical Book Publisher.

[66] Walgito, B. (2017). Introduction to General Psychology (Print 4). Yogyakarta: Andi Offset.

[67] Wawan, \& Dewi. (2017). Theory of Measurement of Knowledge, Attitudes and Human Behavior (Print To). Yogyakarta: Nuha Medika.

[68] Yasin, M., \& Priyono, J. (2016). Analysis of Age, Salary and Dependent Factors on Home Production of Shoe Industry in Sidoarjo (Case Study in Krian District). Journal of Economics And Business, 1 (1), $25-34$. 